\title{
Transfer of Allergic Airway Responses with Antigen-primed CD4+ but not CD8+ T Cells in Brown Norway Rats
}

Azuma Watanabe, Hideyasu Mishima, Paolo M. Renzi, Li-Jing Xu, Qutayba Hamid, and James G. Martin

Meakins-Christie Laboratories, Royal Victoria Hospital, McGill University, Montreal, Quebec, H2X 2P2 Canada

\begin{abstract}
Activated CD4+ helper $\mathbf{T}$ cells have been demonstrated in asthmatic airways and postulated to play a central role in eliciting allergic inflammation; direct evidence of their involvement seems to be lacking. We hypothesized that CD4 + $T$ cells have the potential to induce allergic responses to antigen challenge, and tested this hypothesis in a model of allergic bronchoconstriction, the Brown Norway rat, using the approach of adoptive transfer. Animals were actively sensitized to either ovalbumin (OVA) or BSA and were used as donors of $T$ cells. W3/25(CD4) + or OX8(CD8) + T cells were isolated from the cervical lymph nodes of sensitized donors and transferred to naive $B N$ rats. $2 \mathrm{~d}$ after adoptive transfer recipient rats were challenged by OVA inhalation, and changes in lung resistance $\left(R_{L}\right)$, bronchoalveolar lavage (BAL) cells, and serum levels of antigen-specific IgE were studied. After OVA challenge recipients of OVA-primed W3/25 + T cells exhibited sustained increases in $R_{L}$ throughout the entire 8-h observation period and had significant bronchoalveolar lavage eosinophilia, which was detected by immunocytochemistry using an antimajor basic protein mAb. Recipients of BSA-primed W3/25 $+\mathrm{T}$ cells or OVAprimed OX8 $+T$ cells failed to respond to inhaled OVA. OVA-specific immunoglobulin $E$ was undetectable by ELISA or skin testing in any of the recipient rats after adoptive transfer. In conclusion, antigen-induced airway bronchoconstriction and eosinophilia were successfully transferred by antigen-specific $\mathbf{W} 3 / 25+T$ cells in Brown Norway rats. These responses were dependent on antigenprimed $W 3 / 25+T$ cells and appeared to be independent of IgE-mediated mast cell activation. This study provides clear evidence for $\mathbf{T}$ cell mediated immune mechanisms in allergic airway responses in this experimental model. (J. Clin. Invest. 1995. 96:1303-1310.) Key words: asthma • late response • bronchoalveolar lavage • eosinophils • immunoglobulin $\mathbf{E}$
\end{abstract}

\section{Introduction}

Immediate airway hypersensitivity reactions, provoked by antigen challenge, are frequently followed by delayed airway re-

Address correspondence to J. G. Martin, Meakins-Christie Laboratories, McGill University, 3626 St. Urbain Street, Montreal, Quebec, H2X 2P2, Canada. Phone:514-398-3864; FAX:514-398-7483.

Received for publication 26 September 1994 and accepted in revised form 9 May 1995.

J. Clin. Invest.

(C) The American Society for Clinical Investigation, Inc.

0021-9738/95/09/1303/08 \$2.00

Volume 96, September 1995, 1303-1310 sponses (1). These two responses, the early and late phase airway responses (EAR and LAR), ${ }^{1}$ have several distinctive features based on pathophysiological mechanisms (2). Though the latter response is just a single reaction that follows antigen exposure, it comprises a complex sequence of events including increased airway secretions, enhanced microvascular permeability, allergic inflammation, and the acquisition of airway hyperresponsiveness. All of these phenomena are also central pathophysiologic changes that are observed in chronic asthma (3) and suggest that the mechanisms responsible for the LAR may account for airway inflammation in chronic asthma. There is convincing circumstantial evidence that lymphocytes and their products play a pivotal role in the mechanisms of these pathogenetic changes in asthma. Activated T cells and increased expression or production of $\mathrm{T}$ cell cytokines are demonstrable in asthmatic airways $(4,5)$. The so-called Th2 phenotypic predominance in the bronchial mucosa seems to be a characteristic feature in allergic asthmatic patients (6); the lymphokines elaborated by this CD4+ subset of $\mathrm{T}$ cells, favor the synthesis of IgE over IgG by B cells and promote tissue eosinophilia.

Although the role of $\mathrm{T}$ cells in chronic asthma has been suggested by a number of observations (7), little is known about their role in airway responses after allergen challenge. There is evidence that $\mathrm{T}$ cells are recruited into the airways during allergic responses in humans (8) and animals (9). However, compared to neutrophils and eosinophils, both of which have been postulated to be important mediators of the LAR $(10,11)$, lymphocytes have not been directly implicated in the bronchoconstriction that accompanies the LAR. In an animal model of allergic asthma, Sorkness and coworkers reported that they successfully transferred EARs with antigen-specific IgE in rats, but failed to transfer LARs (12). However, both EARs and LARs were inducible in actively sensitized rats (13). These results suggest that the EAR and LAR are independent events, and that a cellular immune component may be necessary to induce LARs.

Previous observations support a possible role of $\mathrm{T}$ cells in the allergic rat. Firstly, administration of exogenous IL-2, a potent $T$ cell growth factor, resulted in enhancement of LARs in the Brown Norway (BN) rat (14). This study suggested that the activation of $\mathrm{T}$ cells by IL-2 and the subsequent release of other $\mathrm{T}$ cell cytokines might directly modulate the LAR. Secondly, an enhanced LAR to inhaled antigen was present in Sprague-Dawley rats, depleted of CD8 + cells whereas the EAR was not affected (15), indicating an important role CD8 + suppressor/cytotoxic $\mathrm{T}$ cells in attenuat-

1. Abbreviation used in this paper: APAAP, alkaline phosphatase and monoclonal antialkaline phosphatase; BAL, bronchoalveolar lavage; BN, Brown Norway; EAR, early airway responses; LAR, late airway responses; MBP, major basic protein; OVA, ovalbumin; PCA, passive cutaneous anaphylaxis; $R_{L}$, lung resistance. 
ing the LAR, but not the EAR. These effects presumably result from a suppressive action on $\mathrm{CD} 4+\mathrm{T}$ cells. Further confirmation of a CD4 $+\mathrm{T}$ cell contribution to the LAR was obtained by the demonstration that inhibition of $\mathrm{CD} 4+\mathrm{T}$ cell function using an mAb against CD4 blocked the appearance of LAR in the BN rat (16). Since the CD4 surface marker is expressed on basophils, eosinophils, and monocytes as well as helper/inducer $T$ cells, definitive evidence of $C D 4+T$ cell-mediated allergic responses in rats is still lacking.

In the present study, we hypothesised that CD4+ T cells have the potential to induce a late allergic airway response after antigen challenge, and that the response would be similar to the LAR seen in actively sensitized and antigen-challenged animals. To test this hypothesis, we utilized the technique of adoptive lymphocyte transfer in a well characterized model of allergic bronchoconstriction, the BN rat (17-19). This technique is frequently used to investigate cell-mediated immunity in animal models of disease (20-22), and therefore, we expected that this technique would enable us to evaluate the contribution of cell-mediated immunity in allergic responses without the confounding influence of humoral immunity, namely IgE and mast cell-mediated responses.

\section{Methods}

\section{Rats}

Male BN rats and Sprague-Dawley (SD) rats were purchased from a commercial source (Harlan Sprague Dawley Inc.; Walkerville, MD) and maintained in a conventional animal facility at McGill University (Montreal, Canada). Sensitized BN rats were used as donors of antigenprimed $T$ cells, and unsensitized syngeneic $B N$ rats were used as recipients of adoptive $T$ cell transfer. SD rats were used for passive cutaneous anaphylaxis (PCA).

\section{Sensitization}

BN rats, weighing $180-220$ grams and at $7-9 \mathrm{wk}$ of age, were actively sensitized to either ovalbumin (OVA) (grade V; Sigma Immunochemicals, St. Louis, MO) or BSA (fraction V; Sigma Immunochemicals). 1 $\mathrm{mg}$ of antigen was emulsified in aluminum hydroxide solution $(3.5 \mathrm{mg}$ in $1 \mathrm{ml}$ sterile saline; Anachemia Chemicals, Montreal, Canada) and was given subcutaneously with a simultaneous intraperitoneal injection of the adjuvant Bordetella pertussis containing $6 \times 10^{9}$ heat-killed bacilli (IAF; Laval-Des-Rapides, Montreal, Canada).

\section{Antibodies}

W3/25 (MCA P55, mouse anti-rat CD4 $\mathrm{mAb}, \mathrm{IgG}_{1}$ ), MRC OX8 (MCA P48, mouse anti-rat CD8 $\mathrm{mAb} \mathrm{IgG}_{1}$ ) were purchased from Cedarlane Laboratories (Hornby, Canada); MRC OX33 (MCA P49, mouse anti-rat $k$ chain $\mathrm{mAb}_{\mathrm{IgG}}$ ), ED9 (MCA P340, mouse antirat myeloid differentiation antigen, $\left.\mathrm{IgG}_{1}\right)(23)$ were purchased from Prince Laboratories Inc. (Toronto, Canada); MACS rat anti-mouse $\mathrm{IgG}_{1}$ microbeads (No. 471-01) were purchased from Miltenyi Biotec GmbH (Bergisch Gladbach, Germany); mouse anti-rat IgE mAb was obtained from Zymed Laboratories Inc. (South San Francisco, CA) goat anti-mouse FITC labeled IgG was purchased from GIBCO BRL (Gaithersburg, MD). BMK13, a mouse anti-human major basic protein (MBP) Ab, was generously provided by Dr. R. Moqbel (National Heart and Lung Institute, London, United Kingdom) (24).

\section{Immunomagnetic separation of $T$ cell subsets}

$14 \mathrm{~d}$ after sensitization, at which time sensitized $\mathrm{BN}$ rats usually have early and late phase airway responses to inhalational antigen challenge (18), mononuclear cells were harvested from cervical lymph nodes by mincing of the tissue and subsequent passage through a stainless steel sieve. Cells were then washed and passed though a nylon mesh to remove debris, and negative selection using a magnetic cell sorter (MACS; Miltenyi Biotec $\mathrm{GmbH}$ ) was performed according to the manufacturer's instructions. Briefly, undesired cells in the cell suspension were primarily labeled with a mixture of specific mAbs, washed, and indirectly labeled with MACS rat anti-mouse $\mathrm{IgG}_{1}$ microbeads. First cells were treated with either W3/25 or OX-8 in combination with OX33 and ED9, in a dilution of 1:100. The labeled cells were then washed carefully and passed through the MACS column slowly, and the effluent containing the cells of interest was collected. ED9, a mouse anti-rat mAb which recognizes a membrane antigen on rat macrophages, monocytes, dendritic cells, and granulocytes (23), was used to remove nonlymphocytic cells in the cell suspension, whereas OX-33 was used to remove B cells. Cell viability was in excess of $99 \%$.

\section{Adoptive transfer}

Adoptive transfer of the $T$ cell subsets was performed on day 14, immediately after immunomagnetic $\mathrm{T}$ cell separation. Either purified W3/ $25+$ or OX8+ enriched populations of $\mathrm{T}$ cells were resuspended in sterile PBS. Cells were transferred by an intraperitoneal injection to unsensitized, syngeneic recipient BN rats. For the administration of 2 million W3/25+ cells one donor animal was used to provide cells for two recipients. For 20 million W3/25 + cells two donors were used; cells were pooled and administered to two recipients. To transfer 2 million OX8 + cells either three or four donors were used to pool cells for administration to two recipients. $2 \mathrm{~d}$ after the $\mathrm{T}$ cell transfer the recipients were challenged with aerosolized OVA and analyzed for changes in lung resistance $\left(R_{L}\right)$, BAL leukocytes, and serum levels of antigen-specific IgE.

\section{Measurement of airway responses to OVA (18)}

After adoptive transfer $2 \mathrm{~d}$ were allowed to elapse before antigen challenge to permit the location of transferred $T$ cells to stabilize. Animals were anesthetized by an intraperitoneal injection of urethane (1.1 grams/ $\mathrm{kg}$ ), instrumented for the measurement of $R_{L}$, and challenged with OVA (5\% wt/vol) using a Hudson nebulizer (model 1400; Temecula, CA) with an airflow of 10 liter/min for $5 \mathrm{~min}$. Transpulmonary pressure (Ptp) and respiratory air flow (V) of the animals were measured at 15min time intervals for a total period of $8 \mathrm{~h}$. A commercial software package (RHT Infodat Inc., Montreal, Canada) was used to determine pulmonary resistance $\left(R_{L}\right)$ which was obtained by fitting the equation Ptp $=\mathrm{E}_{\mathrm{L}} \mathrm{V}+\mathrm{R}_{\mathrm{L}} \dot{\mathrm{V}}+K$ to a 10-s segment of data, where $\mathrm{E}_{\mathrm{L}}$ is elastance, $\mathrm{V}$ is volume obtained by integration of $\dot{\mathrm{V}}$, and $K$ is a constant.

\section{Bronchoalveolar lavage}

BAL was performed at the end of the $R_{L}$ measurement, $8 \mathrm{~h}$ after OVA challenge. The lungs were lavaged through the endotracheal tube with $10 \mathrm{ml}$ of chilled PBS. The total cell number was counted on a fresh specimen using a hemocytometer. Glass slides were coated with polyL-lysine (molecular weight $>150,000$; Sigma Immunochemicals) before use, and cytospin slides were prepared using a Cytospin model II (Shandon Inc., Pittsburgh, PA) and air-dried for $5 \mathrm{~min}$. For cell differential counts a May-Grünwald-Giemsa stain was used.

\section{Staining procedure for immunocytochemistry}

Cytospin BAL slides were also prepared on poly-L-lysine-coated slides for immunocytochemistry, and were stored at $-80^{\circ} \mathrm{C}$ until analysis. BAL cells were immunostained with BMK13 mAb, a mouse antihuman MBP $\mathrm{mAb}$, using the alkaline phosphatase antialkaline phosphatase (APAAP) method (25). MBP positive cells were quantified by microscopy by an investigator blinded to group status (Q. Hamid). A minimum of $500 \mathrm{BAL}$ cells was counted and the percentage of cells expressing MBP immunoreactivity was evaluated.

To ensure that the immunostaining obtained in the rat BAL cells using the anti-human antibody was specific, a preabsorption test was performed using an excess of MBP antigen extracted from eosinophil 
granules. After preabsorption no significant signal was detected with the use of BMK13.

\section{OVA-specific Immunoglobulin E by ELISA}

ELISA was performed as previously described (26). Briefly, 96-well assay plates (Corning Glass Works, Corning, NY) were coated overnight at $4^{\circ} \mathrm{C}$ with $200 \mu \mathrm{l}$ of the mouse anti-rat IgE mAb in carbonate/ bicarbonate buffer $(2 \mu \mathrm{g} / \mathrm{ml})$. The plates were washed four times with PBS-Tween-azide $\left(0.05 \%\right.$ Tween $20,0.01 \% \mathrm{NaN}_{3}$ in PBS at pH 7.4) and blocked with $0.5 \%$ casein and $0.1 \%$ Tween 20 in PBS. Then plates were successively treated with $100 \mu \mathrm{l}$ of diluted rat serum samples (1:10) at $37^{\circ} \mathrm{C}$ for $1 \mathrm{~h}, 100 \mu \mathrm{l}$ of biotinylated OVA $(0.02 \mathrm{mg} / \mathrm{ml})(27)$ at $37^{\circ} \mathrm{C}$ for $1 \mathrm{~h}$, and alkaline phosphatase conjugated streptavidin (1:500 dilution, Sigma Immunochemicals) at $20^{\circ} \mathrm{C}$ for $30 \mathrm{~min}$. After addition of p-nitrophenyl phosphate disodium (Sigma Immunochemicals) as a substrate plates were developed at $20^{\circ} \mathrm{C}$ for $5-15 \mathrm{~min}$, and spectrophotometrically read at $405 \mathrm{~nm}$ with an ELISA plate reader (400 ATC, SLT Lab Instruments, Pittsburgh, PA).

\section{Allergen skin testing}

Passive cutaneous anaphylaxis. SD rats, weighing 250-300 grams and between 3 to 4 mo of age, were injected intradermally with $100 \mu \mathrm{l}$ of serially diluted sera obtained from the recipients $\mathrm{BN}$ rats. After a period of $48 \mathrm{~h}$, the animals were challenged by intravenous injection of $1 \mathrm{ml}$ sterile saline containing $1 \mathrm{mg}$ OVA and $1 \%$ Evans blue. Extravasation of the dye was measured $30 \mathrm{~min}$ after the challenge, and a reading that was $>5 \mathrm{~mm}$ was considered as a positive PCA reaction as previously described (28). The sera of the donor BN rats were pooled and used as a positive control, and PBS as a negative control.

Intradermal skin tests. Intradermal skin testing was performed in normal unsensitized rats $(n=4)$, actively sensitized rats $(n=4)$, and recipients of 2 million $\mathrm{W} 3 / 25+$ cells $(n=4)$ from sensitized donors. A range of OVA concentrations from $10 \mu \mathrm{g} / \mathrm{ml}$ to $50 \mathrm{mg} / \mathrm{ml}$ (in saline) was tested. A $20-\mu l$ volume of each solution was injected intradermally in the skin of the abdominal wall. $15 \mathrm{~min}$ later $1 \mathrm{ml}$ of $1 \%$ Evans blue dye was given intravenously and the magnitude of the wheal evaluated from the area of the extravasated dye. An area of blue coloration of $>3 \mathrm{~mm}$ in two diameters was considered a positive reaction. Skin tests to BSA were also performed for comparison purposes.

Statistical analysis. Data are presented as mean \pm SEM. Statistical comparison was performed using Student's $t$ test for unpaired variables, an ANOVA, and Newman Keul's Range tests for comparisons among several means, and the Mann-Whitney and Kruskal-Wallis tests for nonparametric data. Where necessary the level of statistical significance was adjusted using the Bonferonni correction, and a $P<0.05$ was considered as statistically significant. Linear regression analysis was done using the technique of least squares to analyze the relationship between variables. Data were analyzed using a commercial statistical package (Number Cruncher Statistical Systems, Kaysville, UT).

Table I. Flow Cytometry Analysis of Mononuclear Cells from Cervical Lymph Nodes and Purified Cells after Immunomagnetic Cell Separation

\begin{tabular}{lcc}
\hline \multicolumn{1}{c}{ mAb } & $\begin{array}{c}\text { MNCs } \\
\text { (mean } \pm \text { SEM) }\end{array}$ & $\begin{array}{c}\text { After MACS* } \\
\text { (mean } \pm \text { SEM) }\end{array}$ \\
\hline Control Ab & $\%$ & $\%$ \\
W3/25(CD4)+ cells & $1.2 \pm 0.6$ & $0.7 \pm 0.1$ \\
OX8(CD8)+ cells & $59.8 \pm 7.4$ & $98.9 \pm 0.8$ \\
OX33+ cells (B cells) & $6.3 \pm 2.1$ & $0.6 \pm 0.1$ \\
ED9+ cells & $28.9 \pm 10.5$ & $0.7 \pm 0.0$ \\
& $4.4 \pm 2.7$ & $1.1 \pm 0.5$
\end{tabular}

* MACS, immunomagnetic cell separation.

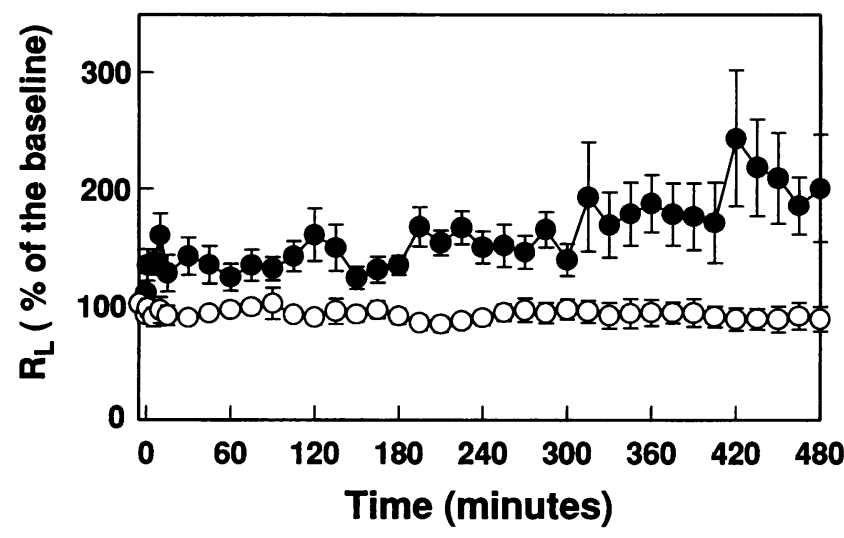

Figure 1. Time course of changes in lung resistance $\left(R_{L}\right)$ after OVA challenge in the recipients of either W3/25+ or OX8 + cells from sensitized rats. Naive BN rats received either purified 2 million W3/ $25+$ cells (CD4+ (2) group) or OX8+ cells (CD8+ group), which were obtained from OVA-sensitized donors $14 \mathrm{~d}$ after the sensitization. $2 \mathrm{~d}$ later the recipients were inhalationally challenged with $5 \%$ OVA in PBS for $5 \mathrm{~min}$. Rats were analyzed for changes in $R_{L}$ before, at 5, 10, and $15 \mathrm{~min}$ after the OVA challenge, and at 15-min intervals for a total period of $8 \mathrm{~h}$. The baseline value of $R_{\mathrm{L}}$ in the CD4+(2) group (closed circles, $n=6$ ) was $0.186 \pm 0.017 \mathrm{~cm} \mathrm{H}_{2} \mathrm{O} / \mathrm{ml}$ per s, and $0.203 \pm 0.08$ $\mathrm{cm} \mathrm{H}_{2} \mathrm{O} / \mathrm{ml}$ per $\mathrm{s}$ in the $\mathrm{CD} 8+$ group (open circles, $n=6$ ). A significant effect between groups was demonstrated by ANOVA $(P<0.001)$.

\section{Results}

Cell phenotype of transferred $T$ cells. The results of CD4 purification were assessed by flow cytometry and demonstrated that the immunomagnetic separation resulted in a successful enrichment of $\mathrm{W} 3 / 25+(\mathrm{CD} 4+)$ cells to almost $99 \%$ purity (Table I). There was $<1 \%$ of OX8 $+(\mathrm{CD} 8+) \mathrm{T}$ cells or B cells after purification.

The purity of OX8 + cells was also evaluated and averaged $\sim 60 \%$. Less than $10 \%$ of the contaminating cells were W3/ $25+$ and $<1 \%$ were either B cells or cells of myeloid lineage.

$T$ Cells and late airway responses. To investigate whether helper $\mathrm{T}$ cells induce allergic airway responses, we transferred either W3/25+ or OX8 + enriched cells obtained from OVAsensitized rats and measured $R_{L}$ in the recipients after antigen challenge. As shown in Fig. 1, recipients of $2 \times 10^{6} \mathrm{~W} 3 / 25+$ cells, CD4+ (2) group, exhibited increases in $R_{L}$, whereas those of $2 \times 10^{6} \mathrm{OX8}+$ cells, CD8 + (2) group, exhibited no responses. This result indicates that allergen-induced bronchoconstriction depends on antigen-primed CD4+ T cells.

To rule out the possibility that antigen-primed CD4 $+\mathrm{T}$ cells induce nonspecific airway responses after foreign protein inhalation, we investigated airway responses after OVA challenge in the recipients of $\mathrm{W} 3 / 25+\mathrm{T}$ cells that were purified from animals sensitized with either OVA or BSA. The CD4+ (20) group received $20 \times 10^{6} \mathrm{~W} 3 / 25+$ cells from OVA-sensitized animals, and the control group received $20 \times 10^{6} \mathrm{~W} 3 /$ $25+$ cells from BSA-sensitized animals. After OVA challenge $R_{L}$ in the CD4+ (20) group increased and was elevated throughout the entire 8-h observation period, whereas that of the control rats remained unchanged (ANOVA, $P<0.0001$; Fig. 2), confirming the specificity of the helper $T$ cells in the induction of bronchoconstriction after antigen challenge. 


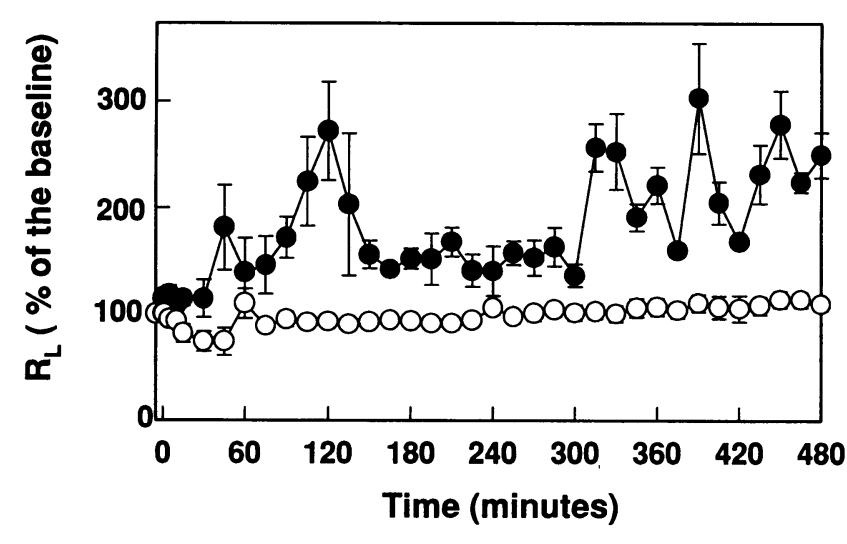

Figure 2. Time course of changes in lung resistance $\left(R_{L}\right)$ after OVA challenge in the recipients of purified $\mathrm{W} 3 / 25+$ cells which were primed to either OVA or BSA. BN rats were sensitized to either OVA or BSA on day 0 . On day $14 \mathrm{~W} 3 / 25+$ cells were isolated from the cervical lymph nodes of sensitized animals and were transferred to naive, syngeneic BN rats. CD4+ $(20)$ group (closed circles, $n=4)$ received 20 million W3/25+ cells from OVA sensitized donors and control group (open circles, $n=6$ ) received 20 million W3/25+ cells from BSA sensitized donors. On day 16 the recipients were challenged by aerosolized OVA as described in Fig. 1. The baseline values of $R_{L}$ between the groups were not significantly different $\left(0.203 \pm 0.016 \mathrm{~cm} \mathrm{H}_{2} \mathrm{O} / \mathrm{ml}\right.$ per $\mathrm{s}$ for $\mathrm{CD} 4+(20)$ group and $0.197 \pm 0.08 \mathrm{~cm} \mathrm{H}_{2} \mathrm{O} / \mathrm{ml}$ per $\mathrm{s}$ for the control group). A significant effect between groups was demonstrated by ANOVA $(P<0.001)$.

After antigen challenge the changes in $R_{L}$ observed in this study lacked the brisk increases which are usually seen immediately after the antigen challenge in actively sensitized $\mathrm{BN}$ rats $(17,18)$. The small increase in $R_{L}$ after OA challenge in the CD4+ (2) group did not reach statistical significance. However, the slowly developing and sustained increases in $R_{L}$ seen in this study indicate the development of allergen-induced LAR. We quantified these increases in $R_{L}$ during the late phase responses by calculating the area under the $R_{L}$ vs time curve (AUC) above the baseline values from 3 to $8 \mathrm{~h}$ after OVA challenge. Fig. 3 shows the mean AUC in each group; recipients of OA-sensitized CD4+ T cells, CD4+ (2) and CD4+ (20) groups, exhibited statistically significant AUC compared to controls and the CD8+ (2) group $(P<0.02)$.

Effect of adoptive transfer on the cellular profile in the BAL after antigen challenge. BAL was performed at $8 \mathrm{~h}$ after antigen challenge to see if allergic inflammation was provoked in this experimental model. As shown in Fig. 4, despite the significant bronchoconstriction induced by $\mathrm{W} 3 / 25+$ cell transfer from sensitized donor animals, no significant changes were observed in either total cell counts or cell differentials. There were two rats that had an extremely high number of eosinophils compared to other rats in the same group, and these two outlying values (63.9\% in CD4+ (2) group and $31.2 \%$ in control group) were excluded from the analysis.

Eosinophilia in BAL detected by immunocytochemistry. The eosinophil number in BAL was assessed by APAAP using an anti-MBP mAb. In contrast to the results obtained by conventional staining, there were significantly higher numbers of eosinophils in the test groups which received antigen-primed CD4+ T cells $(P<0.05$, Fig. 5$)$. The discrepancy in the eosinophil counts between the two staining methods prompted us to ana-

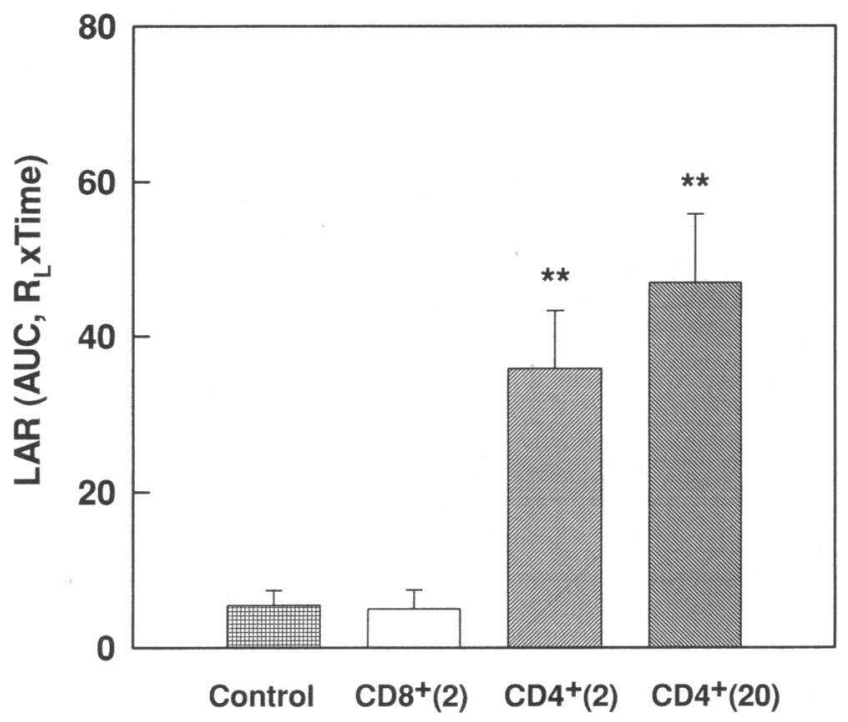

Figure 3. Late phase airway responses after OVA challenge. To compare the magnitude of individual airway responses induced by antigen challenge, we calculated the area under the $R_{L}$ curve after the OVA challenge in each rat. This calculation was done by determining the area under the $R_{L}$ curve against time, above the baseline value, from 3 to $8 \mathrm{~h}$ after the OVA challenge ( $\mathrm{cm} \mathrm{H}_{2} \mathrm{O} / \mathrm{ml}$ per $\mathrm{s} \times$ minutes). Kruskal-Wallis test was used; ${ }^{* *}$ significant statistical difference $(P<0.01)$.

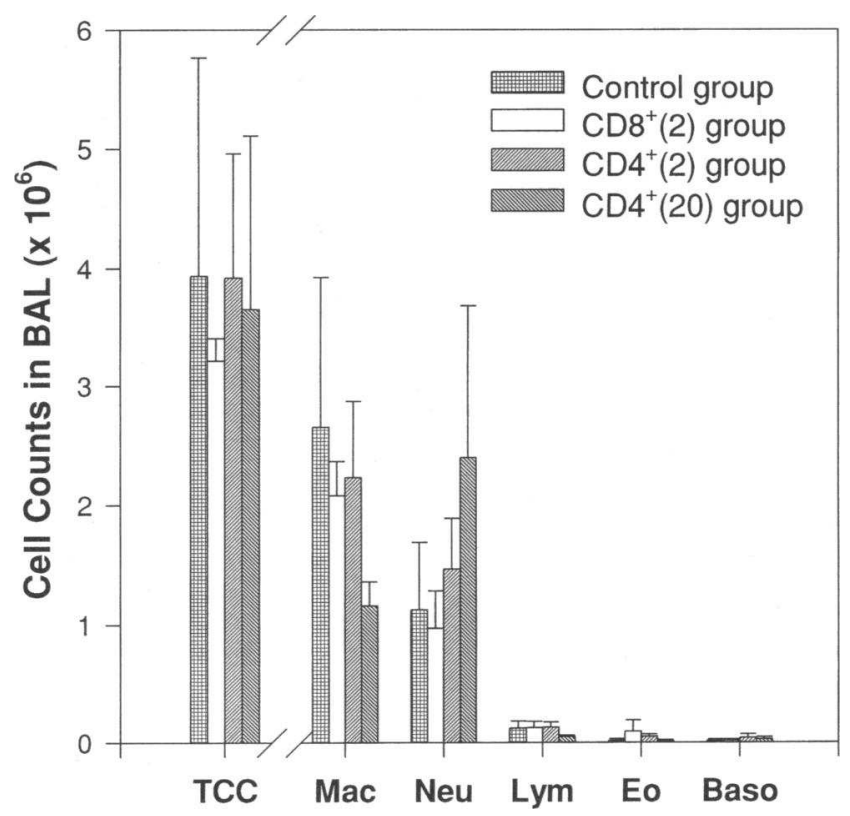

Figure 4. Effect of adoptive transfer on cellular profile in BAL performed at $8 \mathrm{~h}$ after OVA challenge. BAL was performed with $10 \mathrm{ml}$ instillation of chilled PBS at the end of $R_{L}$ measurement. Cytospin BAL slides were prepared and assessed by May-Grünwald-Giemsa staining. The control group received 20 million $\mathrm{W} 3 / 25+$ cells from BSA-sensitized animals; the CD8+ group received 2 million OX8+ cells from OVA-sensitized animals; CD4+ (2) group received 2 million W3/25+ cells from OVA-sensitized animals; and CD4 $+(20)$ group 20 million W $3 / 25+$ cells from OVA-sensitized animals. 


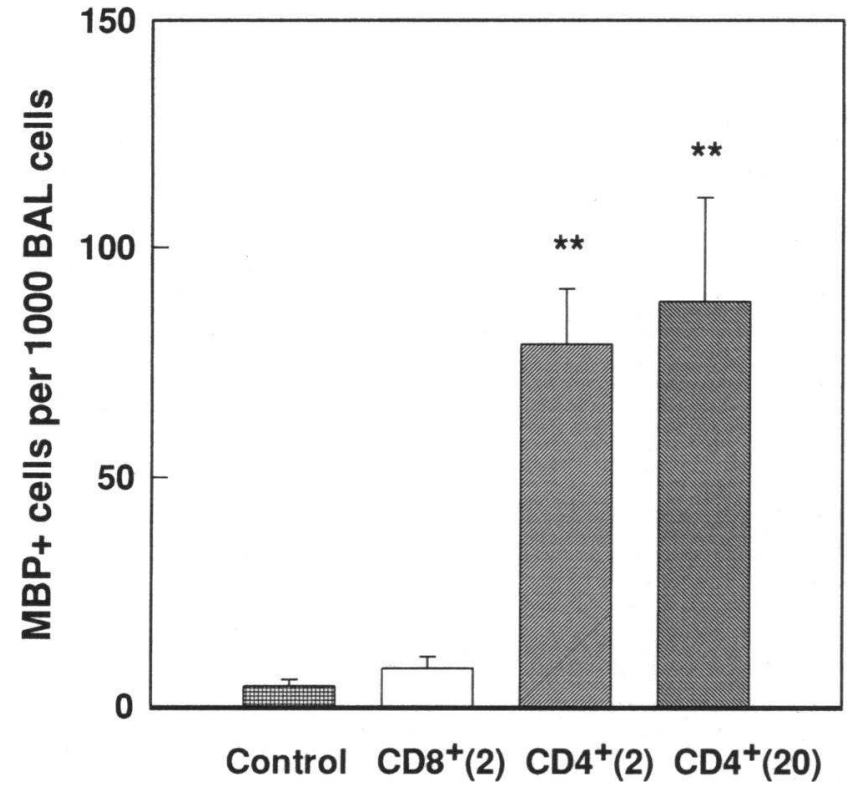

Figure 5. Eosinophil counts in BAL by immunocytochemistry. Eosinophil counts were assessed by APAAP using BMK13, an anti-human MBP mAb, on BAL slides prepared at the same time with those in Fig. 4. The recipients of OVA-primed helper T cells, CD4+(2) and CD4 $+(20)$ groups, had significant BAL eosinophilia compared to control and CD8+ groups $(* * P<0.01)$.

lyze the individual data. Fig. 6 shows a correlation analysis of eosinophil counts between the two staining methods. This analysis disclosed that with two exceptions the number of eosinophils was underestimated by May-Grünwald-Giemsa staining. Indeed, there was no significant correlation between MBP-positive cells in BAL and the magnitude of LARs in the recipients of antigen-primed helper T cells $(r=0.021 ; n=10)$.

Effect of the adoptive transfer on the serum level of antigenspecific immunoglobulin E. OVA-specific IgE was measured by indirect solid-phase ELISA. Since standard rat OVA specific IgE is not available commercially, sera of the rats which developed EARs and LARs were pooled and used as positive controls. The sera from unsensitized BN rats were used as negative controls. As listed in Table II, OVA-specific IgE was not detected in the sera of recipient rats at the time of OVA challenge.

Cutaneous allergic reactions. We performed PCA to investigate whether serum factors in the recipients could activate mast cells after antigen challenge. Early responses to intravenously challenged OVA antigen were assessed by the size of the Evans blue extravasation in the skin where the sera from the recipients and control rats were injected $2 \mathrm{~d}$ previously. As shown in Table II, neither the recipient serum nor the negative control evoked an immediate response to the antigen challenge, whereas both positive control and donor serum from OVA-sensitized rats evoked positive PCA reactions.

Skin reactions to intradermally injected OVA in nonsensitized rats, actively sensitized rats and recipients of CD4+ cells $\left(2 \times 10^{6}\right)$ are shown in Table III. At high concentrations of OVA $(>2 \mathrm{mg} / \mathrm{ml}$ ) the majority of animals showed positive skin reactions. Only actively sensitized animals reacted to concentrations below $1 \mathrm{mg} / \mathrm{ml}$ and even at $10 \mu \mathrm{g} / \mathrm{ml}$ two of three of the sensitized animals still reacted. Only very few animals showed positive reactions to BSA at high concentrations.

\section{Discussion}

The present study supports the hypothesis that allergic airway responses may be induced by antigen-specific CD4+ T cells, providing clear evidence of cell-mediated immune phenomena in the LAR of BN rats. After allergen inhalation recipient BN rats of allergen-specific CD4+ T cells exhibited slowly developing and long-lasting airway narrowing, which was also accompanied by BAL eosinophilia as early as $8 \mathrm{~h}$ after the challenge. Of particular interest is the lack of early phase responses after antigen challenge in this experimental model and undetectable serum levels of antigen-specific IgE in the recipient rats. Therefore, the allergic bronchoconstriction and airway eosinophilia observed in this study appear to be independent of IgEmediated mast cell activation, and are most likely caused by the antigen-primed CD4+ $\mathrm{T}$ cells which were transferred to the recipients and subsequently were activated upon antigen exposure. Although the precise mechanisms responsible for the observed bronchoconstriction are not clear, the results highlight the central role of CD4+ T cells in the LAR.

In human asthmatics, the LAR, which appears $3-8 \mathrm{~h}$ after allergen inhalation, is characterized by persistent airway narrowing and airway inflammation (29), and is associated with increased airway responsiveness to inhaled histamine and methacholine (30). In these respects the LAR contrasts with the isolated EAR which is transient and does not appear to be associated with any long-lasting sequelae. Whereas the role of IgE and mast cells in triggering EARs is well estab-

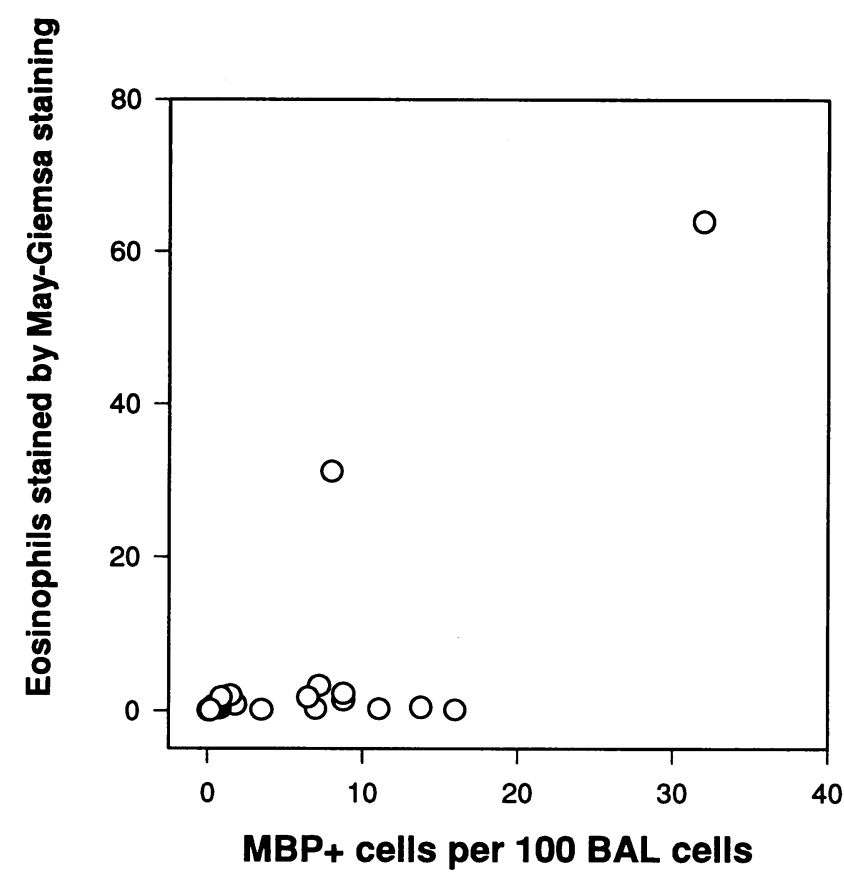

Figure 6. Relationship between eosinophil counts with two different staining procedures. Eosinophil counts in BAL for individual recipient rats were assessed by May-Grünwald-Giemsa staining and compared to the results obtained by immunocytochemistry using BMK13. 
Table II. ELISA for Serum OVA-specific IgE and Passive Cutaneous Anaphylaxis Reactions of the Sera from the Recipient Rats

\begin{tabular}{llrl}
\hline \multicolumn{1}{c}{ Group } & \multicolumn{1}{c}{ Transferred cells } & $\begin{array}{c}\text { OVA-specific IgE } \\
\text { (absorbance units, mean } \pm \text { SEM) }\end{array}$ & Diameters* \\
\hline & & & \\
Control group & BSA-sensitized CD4+ cells & $0.130 \pm 0.003(n=6)$ & $0(n=6)$ \\
CD8+ group & OVA-sensitized CD8+ cells & $0.121 \pm 0.002(n=6)$ & $0(n=6)$ \\
CD4+(2) group & OVA-sensitized CD4+ cells & $0.124 \pm 0.005(n=6)$ & $0(n=6)$ \\
CD4+(20) group & OVA-sensitized CD4+ cells & $0.120 \pm 0.004(n=4)$ & $0(n=4)$ \\
Negative controls & & $0.117 \pm 0.015(n=2)$ & $0(n=2)$ \\
Positive controls & & $1.238 \pm 0.126(n=5)$ & $13.3 \pm 1.4(n=6)$ \\
\hline
\end{tabular}

* The mean diameter of the dye which appeared $30 \mathrm{~min}$ after the antigen challenge was measured (mean $\pm \mathrm{SEM}) .{ }^{\ddagger}$ PBS was used for negative controls. ${ }^{8}$ Sera from OVA-sensitized donor rats were used as positive controls.

lished, the pathogenesis of LARs is less clearly defined. Although recent investigations of the pathogenesis of LARs have focussed on allergic inflammatory cells and their products (2), cellular sources of the relevant cytokines or mediators are yet to be elucidated. For example, IL-5, an eosinophil growth factor as well as an activating and chemotactic factor (31), has been reported to be secreted by $T$ cells (5), mast cells (32), and eosinophils. In addition, peptidoleukotrienes which have been proven to be the major bronchoconstrictive substances in LARs in BN rats (17), have potentially multiple cellular sources including monocytes, macrophages, and mast cells as well as possible transcellular conversion of leukotriene $\mathrm{A}_{4}$ to leukotriene $\mathrm{C}_{4}$ in the lung tissue (33). Our results suggest that activated CD4 $+\mathrm{T}$ cells alone are capable of initiating eosinophil infiltration, a characteristic feature of allergic inflammation, presumably by a mechanism that does not involve mediators released from mast cells. The rapid development of bronchoconstriction after allergen challenge also suggests that $\mathrm{T}$ cell activation triggers other cells which generate the necessary bronchoactive mediators to result in airway smooth muscle contraction.

A decrease in the OKT8+ cells has been demonstrated in subjects suffering from allergic respiratory disease including allergic asthma (34) and supports the hypothesis that the imbalance of the immunoregulatory function of $\mathrm{T}$ cell subsets could lead to the atopic state (35). An analysis of BAL (8) performed in asthmatics $6 \mathrm{~h}$ after antigen challenge showed that subjects who developed an EAR only had an increase in both the percentage and absolute numbers of OKT8+ cells, whereas those who developed dual responses had a higher percentage of OKT4+ cells compared to patients with single EAR. These results prompted the suggestion that recruitment of OKT8+ cells in a relatively early phase of the response might prevent the LAR. Olivenstein and coworkers (15) tested the hypothesis that reducing OKT8+ equivalent cells might increase the LAR in actively sensitized rats (Sprague-Dawley) using an anti-rat $\mathrm{CD} 8 \mathrm{mAb}(\mathrm{OX} 8)$. The results indeed demonstrated that depletion of CD8 + cells enhanced LARs and allergic airway inflammation. As a result of decreased CD8+ T cell numbers, an enhancement of CD4+ cell activity may have occurred and resulted in the LAR. In the present study, adoptive transfer of CD4+ $T$ cells induced dose-dependent increases in LARs in the recipients (Fig. 3). Taken together, these results indicate, not only that the CD4+ cell is responsible for the LAR but that the balance between CD4+ and CD8 $+\mathrm{T}$ cells is likely a major determinant of the expression of the LAR (15).

Adoptive transfer of late airway responses by $\mathrm{T}$ cells in $\mathrm{BN}$ rats provides a unique opportunity to investigate cell-mediated immune responses. We believe that a lack of demonstrable serum antigen-specific IgE precludes the participation of other inflammatory cells through either low- or high-affinity receptors for IgE. Since PCA is a sensitive method to detect antigenspecific IgE and extensively used as an in vivo test (28), the negative outcome of this test indicates that the serum from the

Table III. Intradermal Skin Tests

\begin{tabular}{|c|c|c|c|c|c|c|c|}
\hline & $50 \mathrm{mg} / \mathrm{ml}$ & $10 \mathrm{mg} / \mathrm{ml}$ & $2 \mathrm{mg} / \mathrm{ml}$ & $1 \mathrm{mg} / \mathrm{ml}$ & $500 \mu \mathrm{g} / \mathrm{ml}$ & $100 \mu \mathrm{g} / \mathrm{ml}$ & $10 \mu \mathrm{g} / \mathrm{ml}$ \\
\hline \multicolumn{8}{|l|}{ OVA } \\
\hline $\mathrm{CD} 4+(2)$ rats* & $4 / 4$ & $3 / 4$ & $1 / 4$ & $0 / 4$ & $0 / 4$ & $0 / 4$ & $0 / 4$ \\
\hline Naive rats & $4 / 4$ & $4 / 4$ & $4 / 4$ & $0 / 4$ & $0 / 4$ & $0 / 4$ & $0 / 4$ \\
\hline AS rats ${ }^{\ddagger}$ & $3 / 3$ & $3 / 3$ & $3 / 3$ & $3 / 3$ & $3 / 3$ & $2 / 3$ & $2 / 3$ \\
\hline \multicolumn{8}{|l|}{ BSA } \\
\hline CD4+(2) rats* & $0 / 4$ & $0 / 4$ & $0 / 4$ & $0 / 4$ & & & \\
\hline Native rats & $1 / 4$ & $0 / 4$ & $0 / 4$ & $0 / 4$ & & & \\
\hline AS rats ${ }^{\ddagger}$ & $1 / 3$ & $2 / 3$ & $0 / 3$ & $0 / 3$ & & & \\
\hline
\end{tabular}

A reaction of more than $3 \mathrm{~mm}$ in two diameters was considered positive. The data are expressed as the number of positive skin reactions divided by the total number of animals studied. $* 2$ million $\mathrm{CD}^{+}$cells were transferred. ${ }^{\ddagger}$ Actively sensitized to $\mathrm{OVA}$. 
recipients contained no humoral factor which mediates mast cell activation in the skin. Intradermal skin testing of recipient rats likewise indicated no increase in IgE in these animals although there appeared to be skin reactions to high concentrations of antigen, perhaps reflecting sensitization through dietary exposure. These skin reactions were not augmented by transfer of CD4+ $\mathrm{T}$ cells from sensitized donors arguing strongly that failure to demonstrate OVA-specific IgE in recipient animals is not simply a consequence of the sensitivity of the ELISA and PCA tests. Therefore we conclude that we are observing the contribution of pure cellular immunity to the late allergic response, where formerly mast cell activation has been generally considered to be an essential first step.

The cellular traffic after cell transfer is not defined in this model. The optimal interval between injection of cells and airway challenge is therefore uncertain. Intravenously injected lymphocytes are immediately retained in the pulmonary vasculature and subsequently redistribute throughout the body within $1 \mathrm{~h} \mathrm{(36)}$. Indeed Renz and coworkers challenged mice immediately after transfer of $\mathrm{T}$ cells (37). However, we decided to challenge animals $2 \mathrm{~d}$ after the adoptive transfer, similar to another model of cell-mediated pulmonary disease (20), because previous studies indicated that it takes $18-72 \mathrm{~h}$ to permit the distribution of lymphocytes to stabilize (reviewed in reference 38 ). We have recently demonstrated that intraperitoneal administration of a $\mathrm{T}$ cell-enriched population of cells from sensitized rats results in both allergen induced late responses and hyperresponsiveness to inhaled aerosols of methacholine $32 \mathrm{~h}$ after OVA challenge (39). If, as suggested in the present and previous studies (15), the ratio of CD4/CD8 cells is crucial in induction of the allergic responses, the pattern and time course of the distribution of transferred cells will likely be of importance in determining the outcome of this kind of experiment. It will be interesting also to determine the number of antigen specific CD4+ $\mathrm{T}$ cells required to cause a measurable airway response to challenge.

The results of BAL performed at $8 \mathrm{~h}$ after antigen challenge provided unexpected but potentially important findings regarding eosinophil staining. The immunocytochemical technique disclosed significant BAL eosinophilia in the recipient rats, whereas conventional staining failed to detect it. The reason for this discrepancy is not clear at the present. However, since immunostaining using an anti-MBP mAb is considered to be more reliable in the identification of eosinophils irrespective of their degree of activation (24), we speculate that some of the eosinophils lost their staining properties due to their activation state. These cells may be of the so-called hypodense phenotype (40). If this is true, the implication of this finding is clear. Whether or not conventional staining, which is used to identify the cell type on the basis of the staining properties of cytoplasmic granules, works satisfactorily to identify the cells may depend on the state of cell activation.

Since eosinophils produce a number of mediators such as MBP and eosinophil cationic protein, and these substances have a potential to induce bronchoconstriction, mucus secretion, and epithelial damage (41), a T cell and eosinophil interaction has been postulated to play a role in the LAR. This prompted us to evaluate the relationship between MBP positive cells in BAL and the magnitude of LARs. However, there was no significant correlation between these two parameters in the recipients of antigen-primed helper $\mathrm{T}$ cells. Indeed, we found no correlation between the numbers of any other cell type in BAL and LARs. Thus, the precise link between $\mathrm{T}$ cell activation and bronchoconstriction is missing, and future studies will be required to determine the mechanisms of airway narrowing in this model.

In conclusion, we found that $\mathrm{CD} 4+\mathrm{T}$ cells are responsible for the adoptive transfer of late phase allergic responses in BN rats. Activated $\mathrm{CD} 4+\mathrm{T}$ cells seem to play a role in eosinophil recruitment into the airways, and may have the potential to trigger airway constriction. It does not appear as if a contribution from IgE-mast cell interactions is necessary for the expression of the LAR in the BN rat.

\section{Acknowledgments}

The authors would like to acknowledge with appreciation the helpful criticisms of Dr. Keven Turner.

This work was supported by the Canadian Lung Association, Medical Research Council of Canada (Grant 10381), and the J. T. Costello Memorial Research Fund.

\section{References}

1. Booij-Noord, H., K. Vries, H. J. Sluiter, and N. G. Orie. 1972. Late bronchial obstructive reaction to experimental inhalation of house dust extract. Clin. Allergy. 2:43-61.

2. O'Byrne, P. M., J. Dolovich, and F. E. Hargreave. 1987. Late asthmatic responses. Am. Rev. Respir. Dis. 136:740-751.

3. Lemanske, R. F., Jr. 1992. Mechanisms of airway inflammation. Chest. 101:372S-377S.

4. Walker, C., E. Bode, L. Boer, T. T. Hansel, K. Blaser, and J. C. Virchow, Jr. 1992. Allergic and nonallergic asthmatics have distinct patterns of T-cell activation and cytokine production in peripheral blood and bronchoalveolar lavage. Am. Rev. Respir. Dis. 146:109-115.

5. Robinson, D., Q. Hamid, S. Ying, A. Tsicopoulos, J. Barkans, A. M Bentley, C. Corrigan, S. R. Durham, and A. B. Kay. 1992. Predominant Th2-like bronchoalveolar T-lymphocyte population in atopic asthma. N. Engl. J. Med. 326:298-304.

6. Hamid, Q., M. Azzawi, S. Ying, R. Moqbel, A. J. Wardlaw, C. J. Corrigan, B. Bradley, S. R. Durham, J. V. Collins, P. K. Jeffery, et al. 1991. Expression of mRNA for interleukin-5 in mucosal bronchial biopsies from asthma. J. Clin. Invest. 87:1541-1546.

7. Azzawi, M., B. Bradley, P. K. Jeffery, A. J. Frew, A. J. Wardlaw, G. Knowles, B. Assoufi, J. V. Collins, S. Durham, and A. B. Kay. 1990. Identification of activated $\mathrm{T}$ lymphocytes and eosinophils in bronchial biopsies in stable atopic asthma. Am. Rev. Respir. Dis. 142:1407-1413.

8. Gonzalez, M. C., P. Diaz, F. R. Galleguillos, P. Ancic, O. Cromwell, and A. B. Kay. 1987. Allergen-induced recruitment of bronchoalveolar helper (OKT4) and suppressor (OKT8) T-cells in asthma. Relative increases in OKT8 cells in single early responders compared with those in late-phase responders. Am. Rev. Respir. Dis. 136:600-604.

9. Frew, A. J., R. Moqbel, M. Azzawi, A. Hartnell, J. Barkans, P. K. Jeffery, A. B. Kay, R. J. Scheper, J. Varley, M. K. Church, and S. T. Holgate. 1990. T lymphocytes and eosinophils in allergen-induced late-phase asthmatic reactions in the guinea pig. Am. Rev. Respir. Dis. 141:407-413.

10. De Monchy, J. G. R., H. F. Kauffman, P. Venge, G. H. Koeter, H. M. Jansen, H. J. Sluiter, and K. De Vries. 1985. Bronchoalveolar eosinophilia during allergen-induced late asthmatic reactions. Am. Rev. Respir. Dis. 131:373-376.

11. Murphy, K. R., M. C. Wilson, C. G. Irvin, L. S. Glezen, W. R. Marsh C. Haslett, P. M. Henson, and G. L. Larsen. 1986. The requirement for polymorphonuclear leukocytes in the late asthmatic response and heightened airways reactivity in an animal model. Am. Rev. Respir. Dis. 134:62-68.

12. Sorkness, R., S. Blythe, and R. F. Lemanske, Jr. 1988. Pulmonary antigen challenge in rats passively sensitized with a monoclonal IgE antibody induces immediate but not late changes in airway mechanics. Am. Rev. Respir. Dis. 138:1152-1156.

13. Sorkness, R., K. Johns, W. L. Castleman, and R. F. Lemanske, Jr. 1990. Late pulmonary allergic responses in actively but not passively IgE-sensitized rats. J. Appl. Physiol. 69:1012-1021.

14. Renzi, P. M., S. Sapienza, S. Waserman, D. Tao, R. Olivenstein, N. Wang, and J. G. Martin. 1992. Effect of interleukin-2 on the airway response to antigen in the rat. Am. Rev. Respir. Dis. 146:163-169.

15. Olivenstein, R., P. M. Renzi, J. P. Yang, P. Rossi, S. Laberge, S. Waser- 
man, and J. G. Martin. 1993. Depletion of OX-8 lymphocytes from the blood and airways using monoclonal antibodies enhances the late airway response in rats. J. Clin. Invest. 92:1477-1482.

16. Olivenstein, R., P. M. Renzi, L. J. Xu, J. P. Yang, and J. G. Martin. 1994 Effects of W3/25 monoclonal antibody on pulmonary inflammation and the late airway response in Brown-Norway rats. Am. Rev. Respir. Dis. 149:528a. (Abstr.)

17. Martin, J. G., L. J. Xu, M. Y. Toh, R. Olivenstein, and W. S. Powell. 1993. Leukotrienes in bile during the early and the late airway responses after allergen challenge of sensitized rats. Am. Rev. Respir. Dis. 147:104-110.

18. Eidelman, D. H., S. Bellofiore, and J. G. Martin. 1988. Late airway response to antigen challenge in sensitized inbred rats. Am. Rev. Respir. Dis. 137:1033-1037.

19. Elwood, W., J. O. Loetvall, P. J. Barnes, and K. F. Chung. 1991. Characterization of allergen-induced bronchial hyperresponsiveness and airway inflammation in actively sensitized Brown-Norway rats. J. Allergy Clin. Immunol. 88:951960.

20. Schuyler, M., K. Gott, G. Shopp, and L. Crooks. 1992. CD3+ and CD4+ cells adoptively transfer experimental hypersensitivity pneumonitis. Am. Rev. Re spir. Dis. 146:1582-1588.

21. Caspi, R. R., F. G. Roberge, C. G. McAllister, M. el-Saied, T. Kuwabara, I. Gery, E. Hanna, and R. B. Nussenblatt. 1986. T cell lines mediating experimenta autoimmune uveoretinitis (EAU) in the rat. J. Immunol. 136:928-933.

22. Romball, C. G., and W. O. Weigle. 1987. Transfer of experimental autoimmune thyroiditis with T cell clones. J. Immunol. 138:1092-1098.

23. Damoiseaux, J. G., E. A. Dopp, R. H. Beelen, and C. D. Dijkstra, 1989. Rat bone marrow and monocyte cultures: influence of culture time and lymphokines on the expression of macrophage differentiation antigens. J. Leukocyte Biol. 46:246253.

24. Moqbel, R., J. Barkans, B. L. Bradley, S. R. Durham, and A. B. Kay. 1992. Application of monoclonal antibodies against major basic protein (BMK13) and eosinophil cationic protein (EG1 and EG2) for quantifying eosinophils in bronchial biopsies from atopic asthma. Clin. Exp. Allergy. 22:265-273.

25. Cordell, J. L., B. Falini, W. N. Erber, A. K. Ghosh, Z. Abdulaziz, S. MacDonald, K. A. F. Pulford, H. Stein, and D. Y. Mason. 1984. Immunoenzymatic labeling of monoclonal antibodies using immune complexes of alkaline phosphatase and monoclonal anti-alkaline phosphatase (APAAP complexes). J. Histochem. Cytochem. 32:219-229.

26. Hirano, T., H. Yamakawa, H. Miyajima, K. Maeda, S. Takai, A. Ueda, O. Taniguchi, H. Hashimoto, S. Hirose, K. Okumura, and Z. Ovary. 1989. An improved method for the detection of IgE antibody of defined specificity by ELISA using rat monoclonal anti-IgE antibody. J. Immunol. Methods. 119:145150.

27. Shattil, S. J., M. Cunningham, and J. A. Hoxie. 1987. Detection of activated platelets in whole blood using activation-dependent monoclonal antibodies and flow cytometry. Blood. 70:307-315.

28. Watanabe, N., and Z. Ovary. 1977. Antigen and antibody detection by in vivo methods; a reevaluation of passive cutaneous anaphylactic reactions. $J$. Immunol. Methods. 14:381-390.

29. Metzger, W. J., D. Zavala, H. B. Richerson, P. Moseley, P. Iwamota, M. Monick, K. Sjoerdsma, and G. W. Hunninghake. 1987. Local allergen challenge and bronchoalveolar lavage of allergic asthmatic lungs. Description of the model and local airway inflammation. Am. Rev. Respir. Dis. 135:433-440.

30. Cockcroft, D. W., R. E. Ruffin, J. Dolovich, and F. E. Hargreave. 1977. Allergen-induced increase in non-allergic bronchial reactivity. Clin. Allergy. 7:503-513.

31. Nakajima, $\mathrm{H}$. I Iwamoto, $\mathrm{S}$. Tomoe, $\mathrm{R}$ Matsumura, $\mathrm{H}$. Tomioka, $\mathrm{K}$ Takatsu, and S. Yoshida. 1992. CD4+ T-lymphocytes and interleukin-5 mediate antigen-induced eosinophil infiltration into the mouse trachea. Am. Rev. Respir. Dis. 146:374-377.

32. Bradding, P., J. A. Roberts, K. M. Britten, S. Montefort, R. Djukanovic, R. Mueller, C. H. Heusser, P. H. Howarth, and S. T. Holgate. 1994. Interleukin$4,-5$, and -6 and tumor necrosis factor-alpha in normal and asthmatic airways: evidence for the human mast cell as a source of these cytokines. Am. J. Respir. Cell Mol. Biol. 10:471-480.

33. Sirois, P., Y. Brousseau, H. Salari, and P. Borgeat. 1985. Correlation between the myotropic activity of leukotriene A4 on guinea-pig lung, trachea and ileum and its biotransformation in situ. Prostaglandins. 30:21-36.

34. Engel, P., J. Huguet, J. Sanosa, P. Sierra, N. Cols, and P. A. GarciaCalderon. 1984. T cell subsets in allergic respiratory disease using monoclonal antibodies. Ann. Allergy. 53:337-340.

35. Holt, P. G., C. McMenamin, M. A. Schon-Hegrad, D. Strickland, D. Nelson, L. Wilkes, N. Bilyk, J. Oliver, B. J. Holt, and P. G. McMenamin. 1991 Immunoregulation of asthma: control of T-lymphocyte activation in the respiratory tract. [Review]. Eur. Respir. J. 13:6s-15s.

36. Smith, M. E., and W. L. Ford. 1983. The recirculating lymphocyte pool of the rat: a systematic description of the migratory behaviour of recirculating lymphocytes. Immunology. 49:83-94.

37. Renz, H., J. Saloga, K. L. Bradley, J. E. Loader, J. L. Greenstein, G. Larsen, and E. W. Gelfand. 1993. Specific V-beta T cell subsets mediate the immediate hypersensitivity response to ragweed antigen. J Immunol 151:19071917

38. Berman, J. S., D. J. Beer, A. C. Theodore, H. Kornfeld, J. Bernardo, and D. M. Center. 1990. Lymphocyte recruitment to the lung. [Review]. Am. Rev. Respir. Dis. 142:238-257.

39. Watanabe, A., P. Rossi, P. M. Renzi, L. J. Xu, and R. D. Guttmann. 1995. Adoptive transfer of allergic airway responses with sensitized lymphocytes in BN Rats. Am. J. Respir. Crit. Care. Med. In press.

40. Frick, W. E., J. B. Sedgwick, and W. W. Busse. 1989. Am. Rev. Respir. Dis. 139:1401-1406.

41. Gundel, R. H., L. G. Letts, and G. J. Gleich. 1991. Human eosinophil major basic protein induces airway constriction and airway hyperresponsiveness in primates. J. Clin. Invest. 87:1470-1473. 